\title{
Effect of Ovule Maturity on Recovery of Zygotic Embryos and Embryogenic Cultures from Muscadine Grape
}

\author{
D. J. Gray and L.A. Hanger \\ Central Florida Research and Education Center, Institute of Food and \\ Agricultural Sciences, University of Florida, 5336 University Avenue, Leesburg, \\ FL 34748 \\ Additional index words. Vitis rotundifolia, embryo rescue, ovule culture, somatic \\ embryogenesis
}

Embryogenic and organogenic cell cultures have been reported for several bunch grape cultivars (Gray and Meredith, 1992). Recently, embryogenesis was obtained for the first time in muscadine grape (Vitis rotundifolia Michx., subgenus Muscadinia Planch.) $(2 \mathrm{n}=$ 40) using a unique ovule culture protocol to obtain zygotic embryos, which were then used as explants (Gray, 1992). In this report, we describe the effects of ovule maturity and genotype on the recovery of zygotic embryos and embryogenic cultures from 11 muscadine grape cultivars.

Cultivar vines at the Central Florida Research and Education Center's experimental vineyard in Leesburg wereevaluated for floral development daily during Apr. and May 1991. Flower clusters in which anthesis had occurred in $\approx 25 \%$ of individual flowers were tagged to establish anthesis date. Ovule maturities were based on age in days postanthesis (DPA) $(10,20,30$, and 40). No fewer than 130 ovules for each treatment (each cultivar at each sample date) were dissected from berries and cultured as described by Gray (1992); however, random losses due to contamination resulted in an actual sample range of 109 to 127 ovules among treatments. After 5 weeks in culture, ovules were dissected and the presence of zygotic embryos was determined. To produce embryogenic cultures, ovules from 10-day samples were recultured intact, since cursory examination revealed that zygotic embryos large enough to be recognized through a stereo microscope were not

-Received for publication 13 Aug. 1992. Accepted for publication 19 Oct. 1992. This project was supported in part by the Program in Science and Technology Cooperation, Office of the Science Advisor, U.S. Agency for International Development, grant DHR-5600-G-00-0057-00. Florida Agricultural Experiment Station no. R-02616. Mention of a trademark, proprietary product, or vendor does not constitute a guarantee or warranty of the product and does not imply its approval to the exclusion of other products or vendors that also may be suitable. The cost of publishing this paper was defrayed in part by the payment of page charges. Under postal regulations, this paper therefore must be hereby marked advertisement solely to indicate this fact. present after 5 weeks. With 10-DPA samples, we found that zygotic embryos, embryogenic tissue, or both, when present, emerged from ovules that ruptured during culture. Zygotic embryos from 20, 30, and 40 DPA were cultured to induce somatic embryogenesis as described by Gray (1992). Differences in percentage of ovules with zygotic embryos and percentage of ovules forming embryogenic cultures due to cultivar differences or ovule maturity were determined statistically using a factorial arrangement of treatments in a completely random design.

When data from all sample dates were combined, cultivars differed in the percentage of ovules that contained zygotic embryos (Table 1). A significantly higher percentage of 'Dixie' ovules produced zygotic embryos than those of the other cultivars, except 'Summit'. 'Summit' was intermediate in response but not significantly different from 'Dixie' or 'Regale'. A similar statistically significant overlapping range of responses was evident among all cultivars. Relative ovule maturity also affected zygotic embryo recovery when responses from all cultivars were combined (Table 1). Ovules sampled at 40 DPA produced significantly more zygotic embryos than younger ovules; ovules sampled at 30 DPA responded better than those at 10 or 20 DPA. In previous research, 'Carlos' produced fewer zygotic embryos than 'Dixie', 'Fry', 'Nesbitt', or 'Welder' when only the 20-DPA ovule sample date was tested (Gray, 1992). There was a significant interaction between cultivar and ovule maturity for zygotic embryo recovery (Table 1) due to one instance when ovules from 'Welder' were more responsive at 10 DPA $(13 \% \pm 3 \%)$ than $20 \mathrm{DPA}(4 \% \pm 2 \%)$ and equal in response at $30 \mathrm{DPA}(9 \% \pm 3 \%)$.

There was no difference in the percentage of embryogenic culture lines obtained among cultivars (Table 1). Previously, it was determined that 20-DPA 'Fry' ovules produced significantly more embryogenic cultures than those of 'Carlos', 'Dixie', 'Nesbitt', or 'Welder' (Gray, 1992). However, when compared to the previous tests, $\approx 10 \times$ more replicates per treatment were used in the present study, a procedure that may have led to better statistical resolution. Ovules sampled at 20, 30 , or 40 DPA were similar but produced
Table 1. Effects of cultivar and sample date on recovery of zygotic embryos and embryogenic cultures from muscadine grape ovules.

\begin{tabular}{lccc}
\hline \hline Factors & $\begin{array}{c}\text { Ovules } \\
\text { tested } \\
\text { (no.) }\end{array}$ & $\begin{array}{c}\text { Zygotic } \\
\text { embryos } \\
(\%)\end{array}$ & $\begin{array}{c}\text { Embryo- } \\
\text { genic } \\
\text { cultures } \\
(\%)\end{array}$ \\
\hline Cultivar & & & \\
Dixie & 461 & $21 \mathrm{a}^{\mathrm{z}}$ & $0.9 \mathrm{a}$ \\
Summit & 467 & $18 \mathrm{ab}$ & $1.1 \mathrm{a}$ \\
Regale & 474 & $15 \mathrm{bc}$ & $0.4 \mathrm{a}$ \\
Carlos & 502 & $13 \mathrm{c}$ & $1.6 \mathrm{a}$ \\
Welder & 487 & $13 \mathrm{c}$ & $1.4 \mathrm{a}$ \\
Fry & 472 & $10 \mathrm{~cd}$ & $1.3 \mathrm{a}$ \\
Triumph & 459 & $9 \mathrm{de}$ & $1.3 \mathrm{a}$ \\
Magnolia & 496 & $9 \mathrm{de}$ & $0.6 \mathrm{a}$ \\
Nesbitt & 464 & $7 \mathrm{ef}$ & $0.7 \mathrm{a}$ \\
Noble & 486 & $7 \mathrm{ef}$ & $0.4 \mathrm{a}$ \\
Alachua & 506 & $6 \mathrm{f}$ & $0.8 \mathrm{a}$ \\
DPA & & & \\
10 & 1397 & $1.4 \mathrm{c}$ & $0.07 \mathrm{~b}$ \\
20 & 1324 & $2.7 \mathrm{c}$ & $1.1 \mathrm{ab}$ \\
30 & 1271 & $8.0 \mathrm{~b}$ & $1.0 \mathrm{ab}$ \\
40 & 1300 & $35.0 \mathrm{a}$ & $1.8 \mathrm{a}$ \\
Main effects & & & \\
Cultivar_(CV) & & $*$ & NS \\
Sample time (ST) & & $*$ & $*$ \\
CV $\times$ ST & & $*$ & NS \\
\hline
\end{tabular}

${ }^{2}$ Mean separation in columns by analysis of standard errors from categorical modeling (SAS, 1988). DPA = days postanthesis

${ }^{\mathrm{NS}} *$ Nonsignificant or significant at $P=0.05$, respectively.

significantly more embryogenic cultures than those sampled at 10 DPA. This result demonstrates that ovule or zygote maturity is not critical in obtaining embryogenic cultures.

Newly initiated embryogenic cultures, which resembled those of Vitis longii Prince (Gray and Mortensen, 1987), were placed on growth regulator-free medium and grown as described by Gray (1992). Somatic embryos were germinated on Murashige and Skoog basal medium (Gray, 1992), and resulting plants were acclimated to greenhouse conditions. Representative plants of all cultivars except 'Nesbitt' were established in greenhouse pots. To date, all plants appear normal; they exhibit typical $V$. rotundifolia vegetative morphology, but several years are required to evaluate reproductive morphology. Immature ovules are convenient explants when compared to seeds, which have hard seedcoats that make removing zygotic embryos difficult.

\section{Literature Cited}

Gray, D.J. 1992. Somatic embryogenesis and plant regeneration from immature zygotic embryos of muscadine grape (Vitis rotundifolia) cultivars. Amer. J. Bot. 79:542-546.

Gray, D.J. and C.P. Meredith. 1992. Grape biotechnology, p. 229-262. In: F.A. Hammerschlag and R.E. Litz (eds.). Biotechnology of perennial fruit crops, chapter 9. CAB Intl., Wallingford, England.

Gray, D.J. and J.A. Mortensen. 1987. Initiation and maintenance of long-term somatic embryogenesis from anthers and ovaries of Vitis longii 'Microsperma'. Plant Cell, Tissue \& Organ Cult. 9:73-80.

SAS Institute. 1988. SAS user's guide: Statistics. version 6.03. SAS Institute, Gary, N.C. 